\title{
Strain specific protective immunity induced by pre-erythrocytic infection of toque monkeys with Plasmodium cynomolg
}

\author{
Wathsala Wijayalath', Sandie Cheesman³ , Jagath Rajakaruna', Sudath Weerasinghe', Gamini Kapilananda', \\ Kamal Gamage ${ }^{2}$, Kamal Perera ${ }^{2}$, Shiroma Handunnetti ${ }^{4}$, Richard Carter $^{3}$, Sisira Pathirana ${ }^{1 *}$ \\ From Parasite to Prevention: Advances in the understanding of malaria \\ Edinburgh, UK. 20-22 October 2010
}

Strain specific protective immunity (SSPI) was investigated using two strains of Plasmodium cynomolgi, Pc746 and PcCeylon, in toque monkey. Two groups of monkeys were immunized against either Pc746 ( $n=5)$ or PcCeylon $(\mathrm{n}=4)$, by giving bites with 2-4 sporozoiteinfected Anopheles tessellates mosquitoes per monkey. Primary blood infection was prevented by simultaneous chloroquine cover and secondary, hypnozoite-induced, blood infection was prevented by treating the monkeys one month later with primaquine. The two immunized groups and a group of unimmunized monkeys $(n=4)$ were given a mixed-strain sporozoite challenge infection, 140 and 100 days respectively after immunization. Parasite DNA was collected for 5-8 consecutive days after parasitaemia reached $0.05 \%$ or above. The proportions of the two parasite strains in these samples were quantified using a Pyrosequencing ${ }^{\mathrm{TM}}$ assay based on SNPs in MSP1 and CSP genes. In subsequent blood infections in immunized monkeys the earliest recorded proportion of parasites of an immunizing strain was significantly lower than its proportion in monkeys immunized against a heterologous strain $(\mathrm{P}=0.014$ and 0.027 for the two SNPs) and the proportions of an immunizing strain tended to decline during the period of sample collection. These results show that a parasite strain specific protective immunity to $P$. cynomolgi was indcued following a sporozoite induced pre-erythrocytic infection. This immunity may have been directed against the liver stages or against the blood stage parasites, or against both

'Malaria Research Unit, Dept of Parasitology, Faculty of Medicine, University of Colombo, Colombo, Sri Lanka

Full list of author information is available at the end of the article

\section{Acknowledgements}

Financial support by NSF, Sri Lanka (research grant -RG/2005/HS/14 and scholarship - NSF/SCH/2004/08) and NRC, Sri Lanka 05-66 is acknowledged. SC and RC were supported by a Wellcome Trust Programme Grant.

\section{Author details}

${ }^{1}$ Malaria Research Unit, Dept of Parasitology, Faculty of Medicine, University of Colombo, Colombo, Sri Lanka. ${ }^{2}$ Animal House, Faculty of Medicine, University of Colombo, Colombo, Sri Lanka. ${ }^{3}$ School of Biological Sciences, Institute of Immunology \& Infection Research, University of Edinburgh, UK. ${ }^{4}$ Institute of Biochemistry, Molecular Biology and Biotechnology, University of Colombo, Colombo, Sri Lanka.

Published: 20 October 2010

doi:10.1186/1475-2875-9-S2-P58

Cite this article as: Wijayalath et al.: Strain specific protective immunity induced by pre-erythrocytic infection of toque monkeys with Plasmodium cynomolg. Malaria Journal 2010 9(Suppl 2):P58.

Submit your next manuscript to BioMed Central and take full advantage of:

- Convenient online submission

- Thorough peer review

- No space constraints or color figure charges

- Immediate publication on acceptance

- Inclusion in PubMed, CAS, Scopus and Google Scholar

- Research which is freely available for redistribution

Submit your manuscript at www.biomedcentral.com/submit

\section{Biomed Central}

